\title{
Editorial
}

\section{Corporate Debt}

\author{
Xing (Alex) Zhou \\ Division of Research \& Statistics, Board of Governors of the Federal Reserve System, \\ Washington, DC 20551, USA; Xing.Zhou@frb.gov
}

Received: 1 September 2020; Accepted: 1 September 2020; Published: 4 September 2020

Traditional corporate bond pricing models have had limited success in explaining actual corporate yield spreads. While research conducted over the past decade has substantially improved our understanding of the pricing the corporate debt and the corporate bond markets in general, a number of important questions remain. What are potential risk factors priced in corporate bonds? How do changes in model assumptions affect the explanatory power of bond pricing models? What is the role played by information in determining corporate yield spreads? How important is liquidity for corporate bond issuers? How do various regulations affect the pricing of corporate debts and what are the potential channels? This special issue of the Journal of Risk and Financial Management on Corporate Debt includes six interesting papers that help address these questions.

Lin et al. (2020) studies the credit spread index proposed by Gilchrist and Zakrajsek (2012) (GZ), and shows that it has substantial predictive power for corporate bond returns. They also show that the GZ index has more predictive power than traditional default spread and term structure variables. The superiority of the GZ index is mainly due to its ability to forecast future economic activity. The authors further demonstrate that the GZ index contains valuable information for future corporate bond returns over and beyond that embedded in macroeconomic and policy uncertainty variables.

Yin et al. (2018) proposes a new corporate bond pricing model including both credit rating migration risks and stochastic interest rates. Unlike existing bond models, in which credit rating change is only allowed to occur once with an interest dependent volatility or multiple rating changes with constant interest rate, this model allows volatility to depend on both interest rates and credit rating changes, which can happen multiple times during the life of a bond and are only determined by the issuer's debt-to-asset ratio. The authors discuss calibration to their model parameters with an example, show the bond-value function's numerical graph and their migration interfaces. The model provides a new insight for evaluating the values of corporations with large debt in different macroeconomic and microeconomic environments.

To evaluate the effectiveness of the Corporate Sector Purchase Programme (CSPP) launched by the ECB in March 2016 in the corporate bond market, Cecchetti (2020) decompose the price of a credit default swap (CDS) into an expected losses component and a risk premium component, which is further broken down into two contributions: compensation for changes in the credit environment associated with business and macro conditions (distress risk premium), and the compensation for the risk that the price of the bond falls in the event of default (jump-at-default-risk premium). She then uses the two components of risk premium and the expected losses component to study the main channel through which the CSPP has reduced corporate bond spreads. She finds a more important effect of the CSPP on the component of risk premia and in particular, on the distress risk premium. She also documents some spillover effects of the CSPP to the financial sector, in particular, in terms of expected losses reduction. The methodology introduced by this paper to decompose risk premium also allows for better quantifying the drivers of excess returns in the corporate bond market.

Horny et al. (2018) provide a simple measure of financial integration across the big four member states of the euro area: Germany, France, Italy, and Spain. The authors use dummy regressions to decompose yields of non-financial corporate bonds to disentangle country-specific premia from 
other observable determinants of risks. They derive a synthetic index of corporate bond market fragmentation as the average of the country risk premia in stressed countries, such as Italy or Spain. The study shows that the large changes in the country premia during the European sovereign debt crisis were driven by differences in the expectations of a sovereign default, rather than by changes in corporate issuer fundamentals. They argue the crisis has introduced heterogeneity in the transmission of monetary policy in the euro area, and that such observation should be considered in the adoption and the implementation of non-standard monetary policy measures in the euro area.

Fang-Klingler (2019) studies how the readability of a firm's annual reports affects its corporate bonds. Using two of the most common readability measures, Fog Index (developed by Gunning (1952)) and Total Number of Words, the author shows that US firms with less readable annual reports tend to have higher credit spreads, higher credit spread volatilities, higher transaction costs, higher transaction costs volatility, higher number of trades, smaller trade size, and higher number of trades volatilities in the month following publication of the 10-K filings. Interestingly, the study also provides some evidence that international market participants take readability of the annual report into account when pricing a firm's credit risk. US firms with less readable annual reports also tend to have higher spreads in the EUR corporate bond markets.

Goldstein et al. (2019) studies the link between secondary market liquidity in corporate bonds and the bond's yield spread at issuance. The authors develop measures of a new bond's expected liquidity based on the pre-issuance network centrality for underwriters of the bond. They find that expected liquidity of a bond at issuance has an economically large impact on the cost of raising funds through the corporate bond markets. In particular, a 10\% increase in expected liquidity implies a decrease in the yield spared at issuance of between $8 \%$ and $14 \%$. This finding helps improve our understanding of the impact of liquidity on asset prices.

Funding: This research received no external funding.

Conflicts of Interest: The author declares no conflict of interest.

\section{References}

Cecchetti, Sara. 2020. A Quantitative Analysis of Risk Premia in the Corporate Bond Market. Journal of Risk and Financial Management 13: 3. [CrossRef]

Fang-Klingler, Jieyan. 2019. Impact of Readability on Corporate Bond Market. Journal of Risk and Financial Management 12: 184. [CrossRef]

Gilchrist, Simon, and Egon Zakrajsek. 2012. Credit spreads and business cycle fluctuations. American Economic Review 102: 1692-720. [CrossRef]

Goldstein, Michael, Edith Hotchkiss, and David Pedersen. 2019. Secondary Market Liquidity and Primary Market Pricing of Corporate Bonds. Journal of Risk and Financial Management 12: 86. [CrossRef]

Gunning, Robert. 1952. The Technique of Clear Writing. New York: McGraw-Hill, pp. 36-37.

Horny, Guillaume, Simone Manganelli, and Benoit Mojon. 2018. Measuring Financial Fragmentation in the Euro Area Corporate Bond Market. Journal of Risk and Financial Management 11: 74. [CrossRef]

Lin, Hai, Xinyuan Tao, Junbo Wang, and Chunchi Wu. 2020. Credit Spreads, Business Conditions, and Expected Corporate Bond Returns. Journal of Risk and Financial Management 13: 20. [CrossRef]

Yin, Hong-Ming, Jin Liang, and Yuan Wu. 2018. On a New Corporate Bond Pricing Model with Potential Credit Rating Change and Stochastic Interest Rate. Journal of Risk and Financial Management 11: 87. [CrossRef]

(C) 2020 by the author. Licensee MDPI, Basel, Switzerland. This article is an open access article distributed under the terms and conditions of the Creative Commons Attribution (CC BY) license (http://creativecommons.org/licenses/by/4.0/). 